\title{
GIVING THE NEWS AND THE EMOTIONS EXPERIENCED BY PARENTS WHO HAVE A CHILD WITH SPECIAL NEEDS
}

\author{
Dr. Arbana Zhapaj. \\ Department of Education, University of Vlora, Albania
}

It was the scream from the depths of my heart when I learned that my child would not be born normal, it was the cry of a parent that we all exhale after a great pain "why me ?!”. There was no answer as there has never been.

Pearl Buck (The child who never grew)

The fear parents experience about the future often makes them like their own ingorance.

Mom Eda

\begin{abstract}
Parents of special need children are faced with lack of information to confront reality, contempt, and the unknown. During this phase they have to confront not only the condition of their child, but also their own emotional experience. Receiving the information on the condition of their specialneeds child is the beginning of a long journey that these parents have to probably face all their lifetime. This study tends to identify the needs that parents have at the moment they are communicated the disability of their child and the emotional condition these parents experience. The world is frightening, and special needs children who need to adopt to this world are even more frightened. Stress, anxiety, expectations and parents' emotions are a way to understand how they are precepting the story of their life, and these perceptions and experiences help the professionals to find ways and methods how to help these parents.
\end{abstract}

Key words: special needs children, parents, emotions, news communication.

\section{Introduction}

The structure of family and the concept we have for it are deeply modified compared to the last century. Family is not only a place where we grow up, but also a place where we experience pain, conflict and confusion. However, in the study of family as a structure from the special studies that describe family development, must be assessed not only the first or second generation but also more widened studies of generations. Bringing a child to life is surely a positive aspect for a young family, but it affects the balance of the couple. Giving birth to a special needs child is an event that deeply affects the disruption of family balance, furthermore shocking the condition of this family. The disability is able to challenge the family in its cognitive, emotional and behavioral levels. The couple expresses a worsening of the relation and family perception. Thus, coming of a child may put such pressure on parents, causing a series of psychological, emotive and social elements, constraining the parents to live in an unknown reality never seen before. The first moment after child birth is naturally the moment of getting the information of the disability, a moment which should happen in the presence of a professional, a medical doctor, a psychologist or a psychiatrist. The reactions of parents may vary, each has their own way of reaction. "The handicap" has a great value in the life cycle of the family from now on, as it will reduce and slow the development process.

\section{Methodology}

An important part of the study is the information received from the questionnaires filled by the parents whose children had special needs. There were more than 140 questionnaires filled, but only 120 were completed in total, as the other part did not contain the full information to be analyzed. The questionnaires were completed face to face with the parents and it took us eight weeks to finish. The area where we distributed the questionnaires wereAlbanian cities such as Tirana, Vlore, Berat, Fier, Lezha and Shkodra. The first section of the questionnaire had general questions about the gender, residence, education level and type of disability of 
their children. The second section of the questionnaire required from parents to express their opinion and view on their disabled children. Some of the questions used to get information were: Who communicated to you the news on the child's disability? How important do you think the communication is in relation to: detailed information, psychological help etc. How did you experience the emotions?

The study aimed to assess that the experience of emotion at the moment of receiving information about the child disability is really strong.

\section{Results}

Analyzing of data collectedfrom 120 parents with disabled children showed that $92.5 \%$ were female parents, and $7.5 \%$ e were males. Most of the participants stated that mothers were more involved in the education process, same as (Singler and Butler, 1987, pg, 146. Lipsky (1989) expresses the regret that various studies have not treated the participation of fathers in child education (Graph 1).

\section{Graphic 1 Gender}

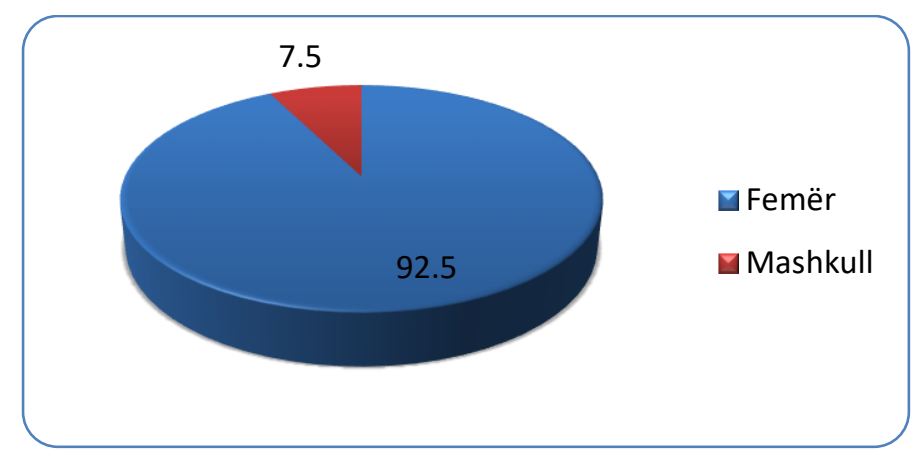

It is known that children with special needs are found in cities and villages. The results of the questionnare showed that $71.7 \%$ come from urbane areas where the population is higher, and such cases of special needs children can be higher. $28.3 \%$ lived in the rural areas (Graph. 2).

Graphic 2 Place of living

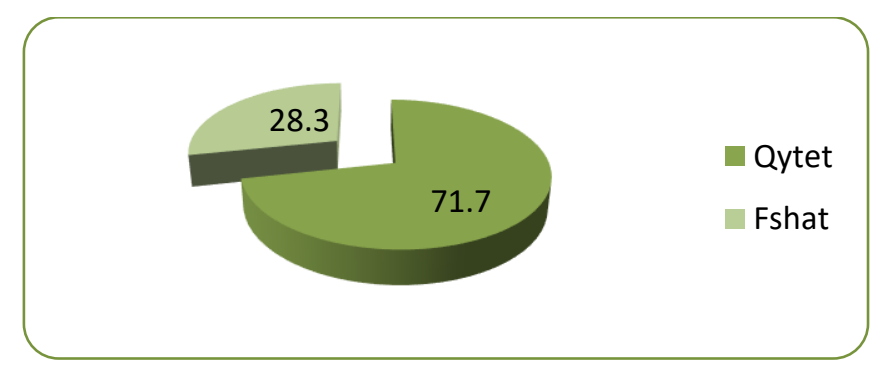

Regarding the parents' employment, we noticed that $33.3 \%$ declared to be employed, while $37.5 \%$ unemployed, $17.5 \%$ were privately employed, and $11.7 \%$ stayed home, mostly mothers as they had to take care of their special need child (Graph. 3).

Graphic 3 Employment 


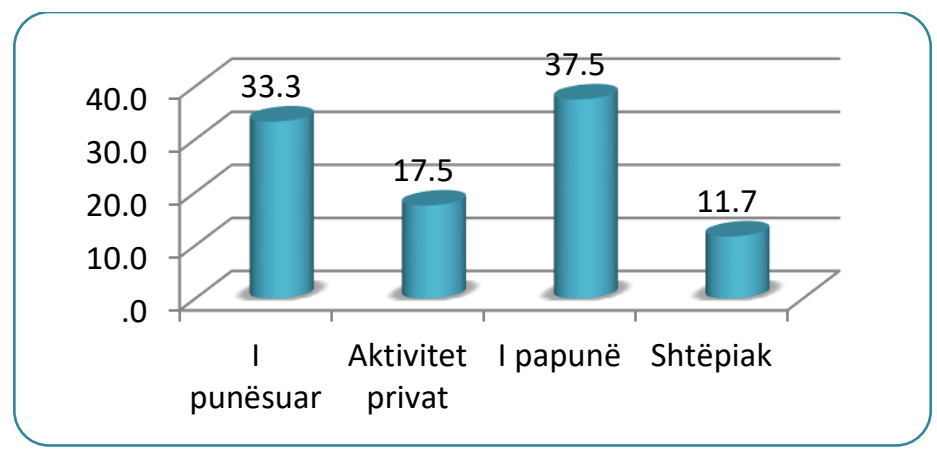

The question on education level, showed that $46.7 \%$ only finished middle school (eight years) and 50\% of these participantslived in the city. $37.5 \%$ had a high school education level and only $15.8 \%$ declared to have earned a university degree.

Table 1 Education level of the parents

\begin{tabular}{|l|l|l|}
\hline & Frequency & Percentage \\
\hline Middle school & 56 & 46.7 \\
\hline High school & 45 & 37.5 \\
\hline University & 19 & 15.8 \\
\hline Total & 120 & 100.0 \\
\hline
\end{tabular}

About the question Who communicated the news? In relation to the child need the parents stated that in $53.3 \%$ of the cases was the specialist who gave them the news, $20.8 \%$ of the parents stated that it was the family doctor, $13.3 \%$ stated that the news came from the psychologist and $10 \%$ and $2.5 \%$, respectively from the family members or the midwife (Table 2).

Table 2: Receiving the information about the child disability

\begin{tabular}{|l|l|l|}
\hline & Frequency & Percentage \\
\hline Family doctor & 25 & 20.8 \\
\hline Specialist & 64 & 53.3 \\
\hline Midwife & 3 & 2.5 \\
\hline Psychologist & 16 & 13.3 \\
\hline Family members & 12 & 10.0 \\
\hline Total & 120 & 100.0 \\
\hline
\end{tabular}

About the question What is important at the moment of communication? 57.5\% of the participating parents stated that Detailed informationis important, and for $17.5 \%$ this information is very important, “... it is important according to me (parent) as in the beginning we do not know the problem that our child has..." these results are similar to the results of other studies (J.M.Bouchard 2009)

The data on the future of the child disability $61.7 \%$ stated that it is important and for $7.5 \%$ is very important. " .... I really need from the professional to explain to me what should I expect from the child and me as a mother..."

About the information regarding the psychological help and the addresses of the societies of parents with special needs children, $67.5 \%$ of the participants state that these were important, while for $4.2 \%$ it was very important. The rest stated that this information wassomewhat important or had little importance. Some declarations of the parents were as follow: “...why should I ask for help when my child will suffer all his life ...", a mother states: "I would prefer not to live than see my child in a wheelchair 
all his life ...", "if I want to help my child, I should help myself, that is why I need the psychological help" expresses another mother.

Table 2 The importance of information

\begin{tabular}{|l|l|l|l|l|l|l|l|l|l}
\hline & $\begin{array}{l}\text { Not } \\
\text { important }\end{array}$ & $\%$ & $\begin{array}{l}\text { Somewhat } \\
\text { important }\end{array}$ & $\%$ & Sufficient & $\%$ & Important & $\%$ & $\begin{array}{l}\text { Very } \\
\text { importan }\end{array}$ \\
\hline $\begin{array}{l}\text { Detailed } \\
\text { information }\end{array}$ & 1 & 0.8 & 18 & 15.0 & 11 & 9.2 & 69 & 57.5 & 21 \\
\hline $\begin{array}{l}\text { Data on the future } \\
\text { of disability }\end{array}$ & 2 & 1.7 & 8 & 6.7 & 27 & 22.5 & 74 & 61.7 & 9 \\
\hline Psychological help & 15 & 12.5 & 13 & 10.8 & 6 & 5.0 & 81 & 67.5 & 5 \\
\hline $\begin{array}{l}\text { Addresses of } \\
\text { ocieties of parents } \\
\text { with special needs } \\
\text { children }\end{array}$ & 15 & 12.5 & 13 & 10.8 & 6 & 5.0 & 81 & 67.5 & 5 \\
\hline
\end{tabular}

Knowing the problems and issues that the families of special need children have, we asked them about their emotive condition. More than half of them $\mathbf{5 5 . 8 \%}$, declared to have felt angry, 23.3\% of the cases this anger was normal. Other studies on this issue in other countries had similar results stating that these types of parents do experience angriness. (J.M.Bouchard, 2006).

Open ended questions where parents express their feelings, we noticed statements such as: ...the anger was endless, why me...? .... I dreamt a beautiful child, and now I see he has Down syndrome ..., .... how could I not be angry?! I get angry with anything, myself, the world, oh my soul knows ...!

75.8\% felt a lot of pain and this is reflected equally in both parents. Experiencing this emotion, the parents stated...it hurts without ending, a ruined life, a destroyed dream, a paralyzed child forever........the pain invades you even when you do not want to, it hurts just to see the child hooked to medical equipment, so little to face this problem and I am so powerless to help ...

In $42.5 \%$ of the cases the parents were extremely shocked. Looking at the comments, the shock was experienced from the expectations that parents had for their children. In this phase the parents were in disbelief, searching for the social cause more than the biological one. In this phase there was also noticed denial of the child or the disability. Expressions such as "he is not my child", "give me my real child" are expressions that were very often seen in parents of such children (Fein \& Dunn 2007), (Siegel 2003).

33.3\% stated that they felt very lonely while in 44 cases or $36.7 \%$ called this normal. Refusal and withdrawal are protective behaviors from the unknown, used by parents to takes time to adopt to the new phenomenon which is already part of their life (Power 2000). Very often these parents chose to withdraw in themselves without accepting any therapy from various professionals (Milani. P. 2007).

$20 \%$ felt very frustrated, $28.3 \%$ very frightened, both parents in general, and mothers in particular.

Experiencing these emotions is really high, this was noticed in the answers of the parents. Other studies on this topic resulted in similar data, where the emotions experienced by parents of special needs children were very high (J.M.Bouchard and J.M. Caloubi 2009 Canada, some centers in Emiglia Romagna 2011, Italy, A.Rada 2014 in Albania etc.).

Most of the parents in their comments stated that: ... the greatest fear is that what is going to happen to my child when I die..., ... I feel the fear each day without knowing what tomorrow will bring ...

Table 3 The experience of emotions 
ISSN 2661-2666 (Online) International Scientific Journal Monte (ISJM) DOI: 10.33807/monte.20211875

Volume 4, (No).2 (2021): April

\begin{tabular}{|l|l|l|l|l|l|l|l|l|l}
\hline & $\begin{array}{l}\text { No } \\
\text { emotions }\end{array}$ & $\%$ & Little & $\%$ & Normal & $\%$ & A lot & $\%$ & $\begin{array}{l}\text { More } \\
\text { than a lot }\end{array}$ \\
\hline Anger & 5 & 4.2 & 18 & 15.0 & 28 & 23.3 & 67 & 55.8 & 2 \\
\hline Pain & 1 & 0.8 & 8 & 6.7 & 13 & 10.8 & 91 & 75.8 & 7 \\
\hline Fear & 11 & 9.2 & 35 & 29.2 & 40 & 33.3 & 34 & 28.3 & 0 \\
\hline Frustration & 13 & 10.8 & 52 & 43.3 & 31 & 25.8 & 24 & 20.0 & 0 \\
\hline Shock & 15 & 12.5 & 29 & 24.2 & 19 & 15.8 & 51 & 42.5 & 6 \\
\hline Loneliness & 10 & 8.3 & 23 & 19.2 & 44 & 36.7 & 40 & 33.3 & 3 \\
\hline
\end{tabular}

\section{Conclusions}

The experiencing of emotions from the parents at the moment of diagnosing and receiving the news on their child disability is really strong.

Comparing the experience of each feeling we can conclude that the emotion that is felt more in parents is anger, followed by pain, shock, loneliness and fear. One of the emotions that accompanies the parent is fear that increases with the level of child's disability. Data of the study showed that fear accompanies the parents since the moment of diagnosing, and later too. More often parents feared the condition itself and also feared what the child would do when the parent was dead... what would happen to the child later.

To study the dynamics of a family with a disabled child is so beautiful, but so hard at the same time. This study identified and evaluated some of these situations making it possible for us to construct ways and find efficient methods in the relations and partnership with these families.

In general, when a child comes to life, he brings joy for the family, and in the case of a disabled child the experience is not normal, as the parents are not prepared for this situation. The study enabled to assess the feelings of the parents at the moment of learning the disability of their child. If we know these feelings of the parents, we can organize the communication methods and relations from the professionals that work with these families. Strengthening the family competencies makes it possible to increase life quality for the child and family. In this perspective, the professionals, family and community societies, the state should facilitate the families into knowing, capacities, and resources necessary to exercise their responsibilities and to be included in the independent life.

In order to include the families in the social services, education, health; to create a partnership between families and professionals and also for the families to get closer to the community is recommended:

Institutions especially state, health, education and rehabilitative ones, in collaboration with parents should develop formation programs to increase awareness of the professionals for the expectations and reality of the family members who have a special needs child and that the partnership with parents and family is the fundamental element in life programs and integration.

There should be more services for the parents by offering counceling and orientation for their rights and the states that parents go through. 


\section{References}

Arbana Zhapaj 2013. Mbi Aftesine e Kufizuar.

Arbana Zhapaj 2011 Pedagogjia e Specializuar

Bouchard J.M, 2002, Partenariat et agir de communication, in Guerdan, V., Bouchard, J-M., Mercier, M., 2002, Partenariat, chercheurs,

praticiens, familles, Montréal, Les Éditions Logiques.

Bronfenbrenner, U. 1986, Ecologia dello sviluppo umano, Bologna, il Mulino.

Broën, R.I., Bayer, M.B., MacFarlane, C. 1989, Rehabilitation Programmes: Performance and Quality of Life of Adults ëith Developmental Handicaps, Lugus, Toronto.

Canali C., Maluccio A., Vecchiato T. (a cura di), 2003, La valutazione di efficacia nei servizi alle persone,

Gargiulo R. 1987, Lavorare con i genitori di bambini handicappati, Zanichelli, Bologna.

Hanau C., Mariani Cerati D. 2003, Il nostro autismo quotidiano. Storie di genitori e figli, Erickson, Trento.

L'Écuyer R. 1990. Méthodologie de l'analyse développementale de contenu., Les Presses de l'Université du Québec,Montréal, Québec.

Maye R., Ouellet F., Saint-Jacques A., Turcotte et coll. éds, Méthodes de recherche en intervention sociale, Gaëtan Morin, Montréal-Paris.Milani P., Qualità della vita e qualità dell'integrazione: la risorsa famiglia, in Ianes D., Tortello M. a cura di, La Qualità dell' integrazione

scolastica. Disabilità, disturbi dell'apprendimento e differenze individuali, Erickson, Trento, 1999.

Pelchat D., Bouchard J.-M. e Lefebvre H. 2001, Progetto d'intervento familiare sistemico e precoce rivolto a genitori di neonaticon deficit e i suoi effetti longitudinali sull'adattamento della famiglia, in Milani P. (a cura di),

Manuale di educazione familiare. Ricerca, intervento, formazione, Erickson, Trento.

Pelchat D., Lefebvre H. 2005, Apprendre ensemble. Le PRIFAM, Programme d'Intervention interdisciplinaire et familiale, Chenelière Education, Montréal.

Khandwalla P., (1976), The Design of Organizations. New York:Harcourt Brace Jovanovich. 